\title{
DIFFERENCES IN TYPE OF BAIT AND FISHING TIME ON TRAP ON THE RESULTS OF THE CATCHES OF BLUE SWIMMING CRABS (PORTUNUS PELAGICUS) IN SOUTH KONAWE WATERS, INDONESIA
}

\author{
Azis M. Aksa*, Nainggolan Chandra, Rahardjo Priyanto \\ Department of Fishing Technology, Faculty of Utilization Fisheries Resources, \\ Fisheries University, Jakarta, Indonesia \\ *E-mail: aksaazis46@gmail.com
}

\begin{abstract}
Blue swimming crab capture operations generally use traps. Trap is a fishing gear that is installed permanently (passive) in water. The purpose of this study was to determine differences in the use of bait types common ponyfish (Leiognathus equulus), goldstripe sardinella (Sardinella gibbosa), trash fish and anchovy (Stolephorus $s p$ ) and soaking time (day and night) of the blue swimming crab (Portunus pelagicus) catches in southern konawe waters. The method used is an experimental fishing method, with two variables namely the type of bait and soaking time with 8 treatments. Primary data collected includes the total weight of the blue swimming crabs (Portunus pelagicus) catch. Data analysis used factorial ANOVA Randomized Design test. The results showed that differences in the use of bait types and soaking time greatly influenced the catch of blue swimming crabs (Portunus pelagicus). Interaction testing shows there is an interaction between the type of bait and the soaking time.
\end{abstract}

\section{KEY WORDS}

Blue swimming crabs (Portunus pelagicus), traps, bait type, soaking time.

South Konawe is one of the regions in Southeast Sulawesi with considerable potential resources. Based on the potential of this area so that most of the people make efforts to catch blue swimming crabs (Portunus pelagicus) as a source of income. Southeast Sulawesi Capture Fisheries Statistics data, the production of blue swimming crab (Portunus pelagicus) in Southeast Sulawesi reached 5,723.4 tons/year, one of the largest contributing regions came from the southern Konawe district, which amounted to 796.7 tons/year. In addition, the annual blue swimming crab (Portunus pelagicus) production data in the southern konawe area showed fluctuating values from 2015-2018 where blue swimming crab (Portunus pelagicus) production was 77 tons, 788 tons, 177 tons and 796 tons respectively. Blue swimming crab (Portunus pelagicus) is a fishery commodity that has a sale value, both as a local commodity and an export commodity. This indirectly is the motivation of fishermen to make efforts to catch blue swimming crabs (Portunus pelagicus).

Fishermen in southern Konawe catch blue swimming crabs (Portunus pelagicus) in general using gillnets and traps. The most dominant fishing gear for catching blue swimming crabs (Portunus pelagicus) is traps. Fishermen in southern Konawe use traps due to nondifficult fishing operations and fishing equipment that is not easily damaged. The traps used are dome shaped and can be folded so it is more efficient to be placed on board. Another advantage that results from traps is a catch that is fresh, alive, and intact in parts of its body, so the selling price is high.

To increase the effectiveness of capture not only on the method of capture that must be considered but also the use of bait types and the right time of capture. Traps fishermen in southern konawe generally use (by catch) the availability of which is uncertain because the danish seine fishermen are operating less and their fishing bases are far from southern konawe. Whereas for the time of their capture, the fishermen catch with uncertain times, for example there are fishermen who catch blue swimming crabs (Portunus pelagicus) only during the day or night, but there are also fishermen who catch blue swimming crabs (Portunus pelagicus) during the day and night depending on the fishermen themselves. 
Based on this, the authors intend to look for the selection of bait and fishing time on the trap is one alternative to improve the effectiveness of capture. In this study the bait used is common ponyfish (Leiognathus equulus), goldstripe sardinella (Sardinella gibbosa), trash fish and anchovy (Stolephorus sp) because it is a fish that is available in large quantities in southern konawe but has not been used maximally by fishermen to be used as fish bait to catch blue swimming crab (Portunus pelagicus). Meanwhile, the time spent in capturing is day and night. In this research, it is hoped that the fish bait can be a new alternative for catching blue swimming crabs (Portunus pelagicus) and can produce effective and efficient conversations.

\section{MATERIALS AND METHODS OF RESEARCH}

The fishing gear used for this study is dome-shaped traps of the size commonly used by fishermen in the southern Konawe district to catch blue swimming crabs (Portunus pelagicus). Traps used in this study have dimensions of length $\mathrm{x}$ width $\mathrm{x}$ height $=45 \times 30 \mathrm{x}$ $15 \mathrm{~cm}$. The traps use a frame made of iron with a diameter of $0.35 \mathrm{~cm}$. Next the traps are closed using a polyethylene multifilament net with a mesh size of $2.5 \mathrm{~cm}$.

The research method used is an experimental fishing method, where researchers directly conduct experiments in the field to collect data. Research activities carried out starting from following the whole series of fisherman activities ranging from the determination of the usual blue swimming crab (Portunus pelagicus) fishing point station to the process of unloading catches.

Traps operation trip was carried out in this study 10 times. Traps used amounted to 100 units, where for each treatment the feed got 25 units and was carried out with 5 replications for each treatment. The design of the experiment in the placement of bait common ponyfish (Leiognathus equulus), goldstripe sardinella (Sardinella gibbosa), trash fish and anchovy (Stolephorus sp) was carried out randomly. Traps operation consists of stages (settings), (soaking time) and (hauling). In this study, two fishing operations were carried out in one day, namely installation in the morning with soaking time of \pm 10 hours, then all traps will be transported and the installation will be immediately done right then and then will be transported again the next day.

The stages of catching data collection at different times (day and night) and with different baits common ponyfish (Leiognathus equulus), goldstripe sardinella (Sardinella gibbosa), trash fish and anchovy (Stolephorus sp) are counting the total number and weight of the catch in each treatment, performing direct observation, interviews, documentation and gathering literature to compare it with the results obtained.

The research design used was a Randomized Group Design which was arranged in factorial consisting of 2 factors, namely:

1. Fishing Time. When fishing is done consists of 2 levels, namely: A1: Day; A2: Night.

2. Bait used. The bait used in the study consisted of 4 levels, namely:

B1: Common ponyfish (Leiognathus equulus);

B2: Goldstripe sardinella (Sardinella gibbosa);

B3: Trash fish;

B4: Anchovies (Stolephorus sp).

Thus there are 8 treatment combinations. Each treatment contained 25 traps samples which were used and repeated 5 times. Total samples observed were 100 traps (Table 1).

Table 1 - Research design

\begin{tabular}{|c|c|c|c|c|c|c|}
\hline \multirow{2}{*}{ Treatment $(A)$} & \multirow{2}{*}{ Treatment $(B)$} & \multicolumn{5}{|c|}{ Group } \\
\hline & & 1 & 2 & 3 & 4 & 5 \\
\hline \multirow[t]{4}{*}{ A1: Day } & B1: Common ponyfish & A1B1 & A1B1 & A1B1 & A1B1 & A1B1 \\
\hline & B2: Goldstripe sardinella & A1B2 & A1B2 & A1B2 & A1B2 & $\mathrm{A} 1 \mathrm{~B} 2$ \\
\hline & B3: Trash fish & A1B3 & A1B3 & A1B3 & A1B3 & A1B3 \\
\hline & B4: Anchovies & A1B4 & A1B4 & A1B4 & A1B4 & A1B4 \\
\hline \multirow[t]{4}{*}{ A2: Night } & B1: Common ponyfish & A2B1 & A2B1 & A2B1 & A2B1 & $\mathrm{A} 2 \mathrm{~B} 1$ \\
\hline & B2: Goldstripe sardinella & A2B2 & A2B2 & A2B2 & A2B2 & A2B2 \\
\hline & B3: Trash fish & A2B3 & A2B3 & A2B3 & A2B3 & A2B3 \\
\hline & B4: Anchovies & A2B4 & A2B 4 & A2B 4 & A2B 4 & A2B4 \\
\hline
\end{tabular}


Based on the design of the experiments conducted, an analysis (ANOVA) with two factors will then be used.

Hypotheses are performed using Analysis (ANOVA) with Hypotheses:

- $\mathrm{H}_{0}$ : Bait and fishing time do not affect the blue swimming crab (Portunus pelagicus) catch on traps;

- $\mathrm{H}_{1}$ : Bait and time of fishing affect the catch of blue swimming crab (Portunus pelagicus) on the trap gear.

Information:

- If the value of Fcount>Ftable, $\mathrm{H}_{0}$ is rejected or there is a difference between treatments;

- Fcount<Ftable, $\mathrm{H}_{0}$ accepted or no difference between treatments.

If the analysis results (ANOVA) give significant results, it will be continued with the Duncan Multiple Rang Test (DMRT) to find out the real difference between the treatment tests given.

\section{RESULTS OF STUDY}

The amount of catch which is a comparison of the 8 treatments in this study in detail can be seen in Table 2.

Table 2 - Comparison of the Number of Catches of Blue Swimming Crabs (Portunus pelagicus)

\begin{tabular}{|c|c|c|c|c|c|c|c|}
\hline \multicolumn{2}{|c|}{ Common ponyfish } & \multicolumn{2}{c|}{ Goldstripe sardinella } & \multicolumn{2}{c|}{ Trash fish } & \multicolumn{2}{c|}{ Anchovies } \\
\hline Day & Night & Day & Night & Day & Night & Day & Night \\
\hline 23 & 23 & 22 & 23 & 22 & 17 & 11 & 6 \\
\hline 16 & 15 & 10 & 14 & 17 & 16 & 13 & 8 \\
\hline 14 & 27 & 10 & 20 & 19 & 28 & 9 & 16 \\
\hline 10 & 11 & 14 & 19 & 11 & 11 & 10 & 13 \\
\hline 12 & 13 & 14 & 18 & 11 & 10 & 9 & 11 \\
\hline 75 & 89 & 70 & 94 & 80 & 82 & 52 & 54 \\
\hline
\end{tabular}

In Table 2, the treatment of fishing carried out during the day with different baits, shows that the use of baits using trash fish has the highest catch (80), common ponyfish (75), goldstripe sardinella (70), and lowest using anchovies (52). Whereas the treatment of catching at night with different bait shows that the goldstripe sardinella bait produces more blue swimming crab (94), common ponyfish (89), trash fish (82) and the lowest using anchovies (54).

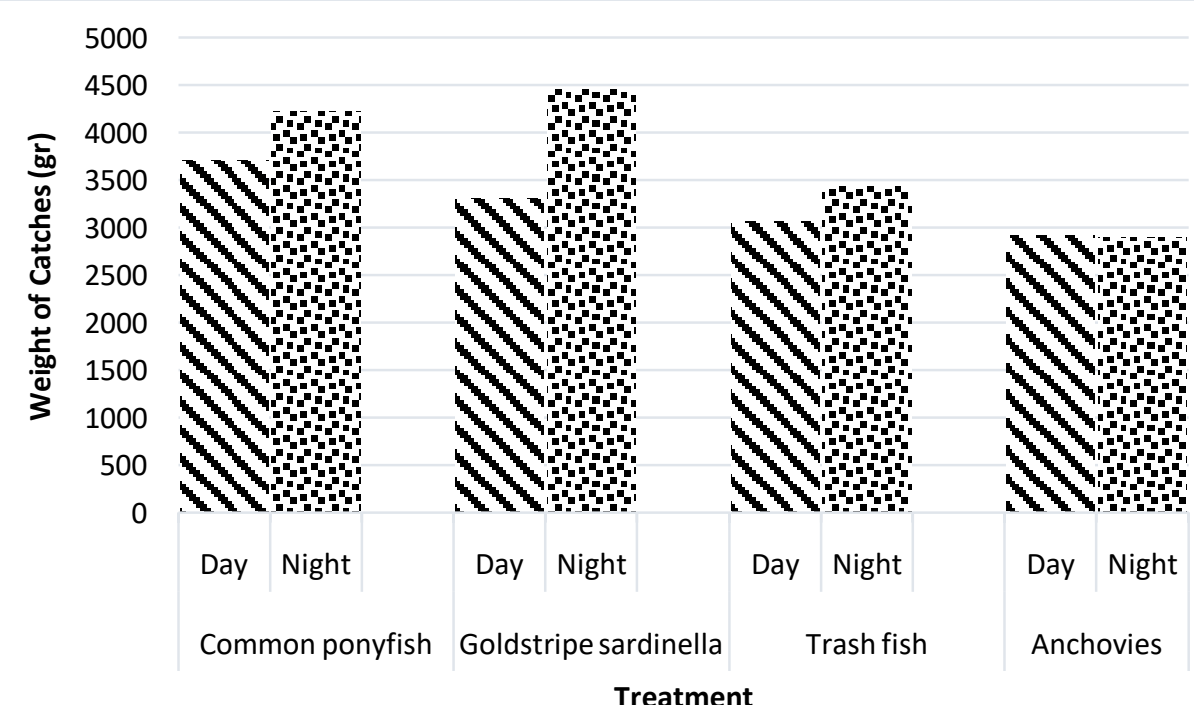

Figure 1 - Comparison of catch weight of blue swimming crab (Portunus pelagicus) 
In Figure 1, the catching treatment carried out during the day with different bait, shows that the use of bait using common ponyfish has the highest catch weight (3708 grams), goldstripe sardinella (3306 grams), trash fish (3063 grams), and the lowest using anchovies (2920 grams). Whereas the treatment by catching at night with different baits shows that the goldstripe sardinella baits produce more blue swimming crab (4455 gram), common ponyfish (4223 gram), trash fish (3430 gram) and lowest using anchovies ( 2902 grams).

Analysis (ANOVA) was conducted with the aim of finding out whether there was a different effect on each treatment. ANOVA test results can be seen in Table 3.

Table 3 - Analysis (ANOVA) of Weight of Catches of blue swimming crab (Portunus pelagicus)

\begin{tabular}{|c|c|c|c|c|c|c|}
\hline \multirow{2}{*}{ SK } & \multirow{2}{*}{$\mathrm{db}$} & \multirow{2}{*}{ JK } & \multirow{2}{*}{ KT } & \multirow{2}{*}{ F count } & \multicolumn{2}{|c|}{$\mathrm{F}$ table } \\
\hline & & & & & $5 \%$ & $1 \%$ \\
\hline Group & 4 & 778745.65 & 194686.4125 & 5.580531915 & 2.71 & 4.07 \\
\hline Combination of $\mathrm{AB}$ & 7 & 481104.175 & 68729.16786 & 1.970067196 & 2.36 & 3.36 \\
\hline Bait & 3 & 159350892 & 53116964 & 1522.555729 & 2.95 & 4.57 \\
\hline Time & 1 & 942891326.4 & 942891326.4 & 27027.23355 & 4.2 & 7.64 \\
\hline Interaction of $A B$ & 3 & 1101761114 & 367253704.7 & 10527.03675 & 2.95 & 4.57 \\
\hline Galat & 28 & 976827.95 & 34886.7125 & & & \\
\hline Total & 39 & 2236677.775 & & & & \\
\hline
\end{tabular}

Based on the ANOVA test results for the combination of $A B$ treatment, the value of Fcount $<$ Ftable $=\mathrm{H}_{0}$ is accepted, which means that there is no difference in treatment between the combination of bait and fishing time for the results of catching blue swimming crab (Portunus pelagicus). Whereas for group treatment, bait, time and between bait interaction and time the value of Fcount $>$ Ftable $=\mathrm{H}_{0}$ is rejected, which means that there is a real difference between the treatment of the blue swimming crab (Portunus pelagicus) captured and the Diversity Coefficient value is $26 \%$.

Based on these results, it is necessary to do further tests, namely the Duncan's Multiple Range Test (DMRT) or commonly known as the Duncan test. Duncan's test results can be seen in Table 4.

Table 4 - Duncan test results

\begin{tabular}{|c|c|c|c|c|c|c|c|c|c|}
\hline $\mathrm{T}$ & Average & 580.4 & 584 & 612.6 & 661.2 & 686 & 741.6 & 844.6 & $\operatorname{lnf}$ \\
\hline A4B2 & 580.4 & 0 & & & & & & & $A$ \\
\hline A4B1 & 584 & 3.6 & 0 & & & & & & $\mathrm{AB}$ \\
\hline A3B1 & 612.6 & 32.2 & 28.6 & 0 & & & & & $A C$ \\
\hline A2B1 & 661.2 & 80.8 & 77.2 & 48.6 & 0 & & & & AD \\
\hline A3B2 & 686 & 105.6 & 102 & 73.4 & 24.8 & 0 & & & $\mathrm{AE}$ \\
\hline A1B1 & 741.6 & 161.2 & 157.6 & 129 & 80.4 & 55.6 & 0 & & AF \\
\hline A1B2 & 844.6 & 264.2 & 260.6 & 232 & 183.4 & 158.6 & 103 & 0 & $B G$ \\
\hline A2B2 & 891 & 310.6 & 307 & 278.4 & 229.8 & 205 & 149.4 & 46.4 & $\mathrm{CH}$ \\
\hline BJND & $(0.05)$ & 242.2384 & 253.9327 & 261.4504 & 267.2976 & 272.3094 & 275.6506 & 278.1565 & \\
\hline BJND & $(0.01)$ & 326.6042 & 340.8044 & 349.1574 & 357.5105 & 362.5223 & 366.6988 & 370.0401 & \\
\hline
\end{tabular}

Table 5 - Blue swimming crab (Portunus pelagicus) is worth catching and not worth catching

\begin{tabular}{|l|l|l|l|}
\hline Category & Bait Type & Day & Night \\
\hline \multirow{4}{*}{ Worth Catching } & Common ponyfish & 25 & 28 \\
& Goldstripe sardinella & 24 & 27 \\
\cline { 2 - 4 } & Trash fish & 12 & 21 \\
\cline { 2 - 4 } Not Worth Catching & Anchovies & 26 & 25 \\
& Common ponyfish & 50 & 62 \\
\cline { 2 - 4 } & Goldstripe sardinella & 46 & 65 \\
\cline { 2 - 4 } & Trash fish & 63 & 64 \\
\cline { 2 - 4 } & Anchovies & 26 & 29 \\
\hline
\end{tabular}

Based on Table 4, the treatment between A1B2 and A2B2 has no significant effect between the two. But based on the two treatments, A2B2 treatment has the highest average value, which is 891 grams, which means that the capture of blue swimming crab (Portunus pelagicus) conducted at night using goldstripe sardinella bait has the best results among all treatments performed. 
In this study, many blue swimming crabs (Portunus pelagicus) were caught small or not feasible to catch, because the fishing operation area is close to the beach or shallow water. The catch of blue swimming crab (Portunus pelagicus) can be seen in Table 5.

\section{DISCUSSION OF RESULTS}

In traps operation, it cannot avoid catches other than blue swimming crabs (Portunus pelagicus), because not only blue swimming crabs (Portunus pelagicus) are attracted by the bait contained in the traps. Other species caught are the type of crab, namely indo-pacific swamb crab (Scylla serrat) and spiral babylon (Babylonia spirata). This is because traps are fishing devices that operate at the bottom of waters targeting demersal species (Subani and Barus, 1989).

The number of catches obtained by time of day and night, shows that the highest number of catches at night. This is because the blue swimming crab (Portunus pelagicus) is an animal that is active at night, so the search for food is done at night. Blue swimming crabs (Portunus pelagicus) are animals that are more active at night than during the day to find food and will swim following the tide to the beach when looking for food (Lino, 2013). The amount of weight that fluctuates between day and night is thought to be caused by the catching area which is installed with traps as a blue swimming crab (Portunus pelagicus) migration path to the spawning place at a certain time (Nontji, 1996 in Lino, 2013).

Based on the catch of the blue swimming crab (Portunus pelagicus) to the time of capture, the number of blue swimming crabs (Portunus pelagicus) that enter the traps get fluctuating results. This is because the blue swimming crab (Portunus pelagicus) will look for food when hungry, and when the blue swimming crab (Portunus pelagicus) feels full, the blue swimming crab (Portunus pelagicus) will move away from that place and will move to another place that is uncertain. Blue swimming crabs (Portunus pelagicus) will approach an area to look for food when they are hungry, and when it is full then blue swimming crabs (Portunus pelagicus) will leave the area and migrate with movement both horizontally and vertically (Gunarso, 1985 in Lino, 2013). Conditions will affect the existence of blue swimming crab (Portunus pelagicus) in an area, ie at a certain time the number of blue swimming crab (Portunus pelagicus) will be high and at a certain time also the number of blue swimming crab (Portunus pelagicus) will be small, thus affecting the number of catches.

The success of capturing using bait is determined by several factors namely the size of the bait, type of bait, chemical content and shape of the bait (Riyanto, et al. 2008).

Blue swimming crab (Portunus pelagicus) is able to detect the presence of bait types through the chemical content carried by currents up to the blue swimming crab (Portunus pelagicus), so that the chemical content in these types of bait influences (Putri, et al. 2013). The water content in the bait causes the chemical content in the bait will spread faster because of the nature of the water that can express various compounds and as a solvent in various other materials (Winarno, 1992 in Putri, et al. 2013).

Use different types of bait in this experiment to determine whether there are differences in catch weight of the four baits. Common ponyfish bait (Leiognathus equulus) and goldstripe sardinella (Sardinella gibbosa) have some characteristics of good bait requirements so that it becomes an option for bait use. A good bait is a bait that is not easily damaged, durable, and not easily decomposed (Pananggung et al., 2014). Trash fish is widely used as bait because the price is cheap and still has good freshness. To maintain the freshness of the three bait, fishermen use salting method for preservation. As for bait anchovies (Stolephorus sp) using ice for preservation because of its easy to break texture. Bait is one of the important factors supporting the success of a fishing process, especially for passive fishing gear such as traps or fishing lines (Iskandar and Rachmad, 2013).

\section{CONCLUSION}

Based on the results of the study it can be concluded that the different types of bait and soaking time affect the catch of blue swimming crab (Portunus pelagicus) and there is an 
interaction between the type of bait and soaking time of the catch of blue swimming crab (Portunus pelagicus). There are more fish catches at night than during the daytime. The best treatment used for catching blue swimming crabs (Portunus pelagicus) is by using a type of bait goldstripe sardinella (Sardinella gibbosa) with soaking time at night.

\section{REFERENCES}

1. Gunarso, W. 1985. Fish Behavior in Relation to Fishing Tools, Methods and Techniques. Bogor: Department of Fisheries Resource Utilization, Faculty of Fisheries, Bogor Agricultural University. $149 \mathrm{Pg}$.

2. Hanafiah K, A. 2016. Theoretical and Application Experiment Design. Rajawali Press. Jakarta.

3. Iskandar D, Caesario R. 2013. Effect of Bait Position on the Catch of Fold Bubu. PSP Bulletin Journal. Vol 21, No 1: 1-9.

4. Lino, W. D. 2013. Comparison of Capture Trap Rajungan Operated Day and Night in the waters of South Sulawei Parepare Coast [THESIS]. Faculty of Marine and Fisheries Sciences. Hasanuddin University. Makassar.

5. Nontji, A. 1996. Nusantara Sea. Djambatan. Jakarta.

6. Pananggung et al. 2016. The Effect of Squid Oil Extract on Bait Traps on the Catch of Mangrove Crabs and Blue Swimming Crab in the Malise Waters of Tabukan Tengah District. Journal of Capture Fisheries Science and Technology. Vol 2, No. 2: 117-121.

7. Putri, R. L. C. Aristi, D. P. and Taufik, T. 2013. Analysis of Differences in Bait Type and Length of Soaking Time on Traps Fishing Equipment on Blue Swimming Crab Catches in Suradadi Tegal Waters. Journal of Fisheries Resources Utilization Management and Technology. 2 (3): 51-60.

8. Riyanto, M. Ari, P. and Budy, W. 2008. Effectiveness of Tiger Grouper (Epinephelus fuscoguttatus) Catching with Traps Using Artificial Bait. FPIK Bogor Agricultural University (IPB). Bogor.

9. Subani W and Barus H, R. 1989. Fishing Tools and Sea Shrimp in Indonesia. Journal of Marine Fisheries Research. Jakarta.

10. Winarno, F.G. 1992. Food Chemistry and Nutrition. PT. Gramedia Main Library. Jakarta. 